\title{
Trellis systems and rootstocks affect the quality and antioxidant potential of 'BRS Cora' grapes in rainy seasons under semiarid conditions
}

\author{
Rayssa Ribeiro da $\operatorname{Costa}^{1}$ (D), Talita de Oliveira Ferreira² (iD), Maria Auxiliadora Coêlho de Lima ${ }^{3, *}$ (iD \\ 1. Universidade Federal da Paraíba - Departamento de Fitotecnia e Ciências Ambientais - Programa de Pós-Graduação \\ em Agronomia - Areia (PB), Brazil. \\ 2. Universidade Federal do Vale do São Francisco - Centro de Ciências Agrárias - Programa de Pós-Graduação em \\ Produção Vegetal - Petrolina (PE), Brazil. \\ 3. Empresa Brasileira de Pesquisa Agropecuária - Centro de Pesquisa Agropecuária do Trópico Semiárido - Fisiologia \\ Pós-Colheita - Petrolina (PE), Brazil.
}

Received: May 5, 2020 | Accepted: Oct. 6, 2020

Section Editor: Cláudia Sales Marinho

*Corresponding author: auxiliadora.lima@embrapa.br

How to cite: Costa, R. R., Ferreira, T. O. and Lima, M. A. C. (2021). Trellis systems and rootstocks affect the quality and antioxidant potential of 'BRS Cora' grapes in rainy seasons under semiarid conditions. Bragantia, 80, e0721. https://doi.org/10.1590/1678-4499.20200201

\begin{abstract}
The quality and phenolic compound composition might be affected by production system due to microclimate around the bunches and sunlight interception provided by vegetative canopy architecture and environmental conditions. The aim of this study was to characterize the quality and antioxidant potential of 'BRS Cora' grapes with different trellis systems and rootstocks in rainy seasons under tropical conditions. Three trellis systems and two rootstocks were studied in production cycles during the first halves of 2017 and 2018, using a randomized-block experimental design. Interactions between the trellis systems, rootstocks and cycles differentially affect the fruit quality. The association between vertical shoot positioning or an overhead trellis with 'IAC 766' induced higher polyphenol compound contents. In turn, the trellis systems overhead trellis and lyre provided greater stability for the berry weight, soluble solids, total soluble sugar contents, yellow flavonoids, total extractable polyphenol compounds or antioxidant activity in both production cycles. The results of this study inferred that the grape quality and phenolic compound composition were not only affected by some specific climatic factors but also by the trellis system, rootstock, and the interaction between the three factors.
\end{abstract}

Key words: Vitis vinifera $\times$ Vitis labrusca, functional appeal, management grapevine, phenolic compounds, tropical vitiviniculture.

\section{INTRODUCTION}

Adequately selected trellis systems, together with a specific rootstock, might increase vegetative and productive growth of grapevines, as they determine different foliar organizations and densities and affect chemical composition of the grape. Depending on canopy architecture, the leaves and bunches of the grapevines may develop either in the shade or totally exposed to solar radiation (Pastore et al. 2017). Trellis systems influence the level of sunlight exposure on the leaves and can change the grapevine physiology as a consequence of the microclimate around the bunches, affecting the grape composition, including phenolic compound contents (Scafidi et al. 2017; Ferreira et al. 2019). Conversely, the rootstock may affect the grapevine physiology and phenology, yield, vigor, fertility, berry size and color, also affecting fruit quality (Jin et al. 2016; Miele and Rizzon 2017).

In Brazil, the Submedium São Francisco Valley is one of the major grape-producing regions, both for consumption in natura and for juice and wine production (Leão et al. 2018). It is located in a semiarid tropical climate zone, with a mean 
temperature of $26^{\circ} \mathrm{C}$, high light incidence and low annual rainfall (Alvares et al. 2013). These climatic conditions differentiate this region from other grape-producing regions. Due to high incidence of local solar radiation and high temperatures, the grapevines do not pass through a dormant period, leading to continuous growth. This behavior combined with irrigation results in at least two harvests a year (Leão et al. 2018). Furthermore, different climatic conditions during the separate harvests in the same year may affect grapevine yield and the characteristics of the grapes. Under tropical conditions, even harvests during the same period or semester can show variations. Therefore, for commercial cultivars it is important to have information on which characteristics are effectively affected by harvest seasons and to what extent. In addition, the extent of the influence of important components of the production system such as trellis systems and rootstocks, on productivity and quality of grapes under these conditions is little known.

The 'BRS Cora' hybrid cultivar is one of the most important genotypes for juice processing in the Submedium São Francisco Valley. It is used in blends since it has a typical Vitis labrusca L. grapes flavor and a colored must. Ribeiro et al. (2012) considered its contribution to increasing the phenolic compound and organic acids contents in juice.

The aim of this study was to characterize the quality and antioxidant potential of 'BRS Cora' grapes grown under different trellis systems and rootstocks in rainy seasons under tropical conditions.

\section{MATERIAL AND METHODS}

The experiment was carried out in a vineyard implemented in December 2015 in the municipality of Petrolina, state of Pernambuco, Brazil ( $09^{\circ} 09^{\prime}$ S, $40^{\circ} 22^{\prime}$ W, altitude of $376 \mathrm{~m}$ ). According to Köppen's classification, climate in the region is BSh, which corresponds to a very hot, semiarid region, where rainfall is concentrated from February to April (Alvares et al. 2013). The 'BRS Cora' grapevines were trained to three trellis systems (overhead trellis - OTS, lyre and vertical shoot positioning VSP, adopting a $3.0 \times 1.0 \mathrm{~m}$ spacing for all of them) and grafted onto two rootstocks ('IAC 572' and 'IAC 766'). The production cycles of the first semesters of two consecutive years were assessed. In the first cycle, the grapevines were pruned on January $16^{\text {th }} 2017$ and the harvest took place in April 27 ${ }^{\text {th }} 2017$; and in the second cycle, the grapevines were pruned on January $24^{\text {th }}$ 2018 and the harvest took place on May $18^{\text {th }} 2018$.

The vine management followed the vitiviniculture recommendations for the Submedium São Francisco Valley (Leão et al. 2009). The vineyards were drip irrigated with water rates applied on a daily basis according to meteorological data collected each day. Table 1 shows the climatic data for the whole period.

The experimental design was in randomized blocks, organized in plots subsubdivided over time, in which the trellis systems corresponded to plots, rootstocks corresponded to subplots, and production cycles corresponded to subsubplots. Four replicates were used, comprised of five vines each. When the berries were ripe and ready to processing, ten bunches were collected from each plot.

The grapes were analyzed for their physical and chemical characteristics. The bunch weight $(\mathrm{g})$ was determined using a VI 2400 semianalytical precision scale (Acculab, Florida, USA) calculating the mean value of 10 bunches. The berry weight (g) was calculated from the mean weight of 50 berries, sampled from the 10 bunches collected and determined using a VI 2400 semianalytical precision scale (Acculab, Florida, USA). The berry resistance to compression (N) was measured using 20 berries, evenly separated from the bunches sampled, the strength required to cause a $20 \%$ compression in berry volume being measured using a digital Extralab TA.XT.Plus texturometer (Stable Micro Systems, Surrey, UK) with a P/75 pressure plate (Ribeiro et al. 2012). Skin color was measured based on the $a^{*}$ and $b^{\star}$ CIELAB parameters using a digital colorimeter (Konika Minolta, model CR-400), determined for the color of 20 representative berries from the bunches sampled.

The chemical composition of grapes was determined using the major quality-driving variables. The titratable acidity (g tartaric acid $100 \cdot \mathrm{mL}^{-1}$ ) was measured using a Metrohm model Titrino plus 848 automatic titrater. The soluble solids content ( ${ }^{\circ}$ Brix) was determined using an ATAGO model PAL-1 digital refractometer with automatic temperature compensation (Horwitz 2010). Total soluble sugars content $\left(\mathrm{g} \cdot 100 \mathrm{~g}^{-1}\right)$ was determined using the anthrone reagent with a Varian Cary 50 Bio UV-Vis spectrophotometer (Yemm and Willis 1954). The total yellow flavonoid and anthocyanin contents in the grape skins ( $\mathrm{mg} \cdot 100 \mathrm{~g}^{-1}$ ) were extracted using the method proposed by Francis (1982), with ethyl alcohol (95\%) and $\mathrm{HCl}(1.5 \mathrm{~N})$ 
Table 1. Monthly meteorological data in the Bebedouro/Embrapa Semiárido Experimental Field during the production cycles of the first halves of 2017 and 2018, when the quality and antioxidant potential of 'BRS Cora' grapes were studied under the influence of different trellis systems and rootstocks.

\begin{tabular}{|c|c|c|c|c|c|c|c|c|}
\hline \multirow{2}{*}{ Month } & \multicolumn{3}{|c|}{$\mathrm{T}\left({ }^{\circ} \mathrm{C}\right)$} & \multirow{2}{*}{$\begin{array}{l}\mathrm{RH} \\
(\%)\end{array}$} & \multirow{2}{*}{$\begin{array}{c}\text { Rad } \\
\left(\mathrm{MJ} \cdot \mathrm{m}^{-2} \cdot \mathrm{dia}^{-1}\right)\end{array}$} & \multirow{2}{*}{$\begin{array}{c}\text { Ws } \\
\left(\mathrm{m} \cdot \mathrm{s}^{-1}\right)\end{array}$} & \multirow{2}{*}{$\begin{array}{l}\text { Rainfall* } \\
\quad(\mathrm{mm})\end{array}$} & \multirow{2}{*}{$\begin{array}{c}\text { ETO } \\
\left(\mathrm{mm} \cdot \mathrm{dia}^{-1}\right)\end{array}$} \\
\hline & Mean & Max. & Min. & & & & & \\
\hline \multicolumn{9}{|c|}{ January $16^{\text {th }}$ to April $27^{\text {th }} 2017$ (Production Cycle 1 ) } \\
\hline Jan/17 & 29.3 & 36.0 & 23.2 & 45.1 & 18.2 & 2.4 & 10.2 & 6.3 \\
\hline Feb/17 & 29.1 & 35.8 & 23.5 & 54.0 & 19.8 & 2.0 & 23.3 & 5.8 \\
\hline Mar/17 & 28.8 & 35.3 & 23.3 & 57.6 & 19.8 & 1.8 & 5.6 & 5.5 \\
\hline Apr/17 & 28.0 & 34.2 & 22.6 & 62.0 & 17.4 & 2.4 & 3.2 & 5.4 \\
\hline Mean & 28.4 & 34.8 & 22.9 & 56.8 & 18.4 & 2.2 & 10.5 & 5.5 \\
\hline \multicolumn{9}{|c|}{ January $24^{\text {th }}$ to May $18^{\text {th }} 2018$ (Production Cycle 2) } \\
\hline Jan/18 & 28.3 & 35.0 & 23.3 & 65.1 & 23.7 & 1.9 & 43.0 & 6.0 \\
\hline $\mathrm{Feb} / 18$ & 27.3 & 33.7 & 23.1 & 80.0 & 21.5 & 1.2 & 66.1 & 4.9 \\
\hline Mar/18 & 27.5 & 34.1 & 23.0 & 81.2 & 22.9 & 0.9 & 109.4 & 4.8 \\
\hline Apr/18 & 26.2 & 32.3 & 21.6 & 79.3 & 20.6 & 1.1 & 100.5 & 4.3 \\
\hline May/18 & 26.0 & 32.8 & 20.3 & 74.5 & 19.3 & 1.6 & 6.7 & 4.3 \\
\hline Mean & 27.1 & 33.6 & 22.3 & 76.0 & 21.6 & 1.3 & 65.1 & 4.9 \\
\hline
\end{tabular}

Mean $\mathrm{T}$. = mean temperature; $\mathrm{T}$. Max. = maximum temperature; $\mathrm{T}$ Min. = minimum temperature; $\mathrm{RH}=$ relative humidity; Rad = global solar radiation; $\mathrm{Ws}=$ wind speed at a 2.0 m height; Rainfall = accumulated rainfall; ET0 = reference evapotranspiration. * Total monthly rainfall. Source: Agrometeorological Station of Bebedouro, Petrolina, Pernambuco, Brazil - Embrapa (2017); Embrapa (2018).

in an 85:15 ratio as the extracting solution. The yellow flavonoids were quantified at $374 \mathrm{~nm}$ using a Varian Cary 50 Bio UV-Vis spectrophotometer, and the total anthocyanins were quantified at $535 \mathrm{~nm}$. The total extractable polyphenols (mg gallic acid $100 \mathrm{~g}^{-1}$ ) were successively extracted in $50 \%$ ethyl alcohol and $70 \%$ acetone solutions from samples comprised of ground skin and macerated pulp, and their contents determined using the Folin-Ciocalteu reagent and 20\% sodium carbonate with a Varian Cary 50 Bio UV-Vis spectrophotometer (Larrauri et al. 1997).

The total antioxidant activity was also quantified using the $\mathrm{ABTS}^{*+}[($ acid 2,2'-azino-bis(3-ethylbenzothiazoline-6sulfonic)] and DPPH (2,2-dyphenyl-1-picryl-hydrazyl) free radical capture methods. The procedures described by Miller et al. (1993) and Sanchez-Moreno et al. (1998) were adopted for ABTS ${ }^{\cdot+}$ and DPPH ${ }^{\bullet}$ methods, respectively, using a Varian Cary 50 Bio UV-Vis spectrophotometer.

The data distribution was evaluated using Shapiro-Wilk test. The data that met the principle of normality were submitted to an analysis of variance, comparing the mean values for the isolated effects of the plots, subplots, and subsubplots as well as their interactions by the F or Tukey's test $(\mathrm{p}<0.05)$. The soluble solids, total soluble sugars, yellow flavonoids, total anthocyanins, total extractable polyphenols and antioxidant activity according to the ABTS ${ }^{\bullet+}$ free radical capture method did not have normal data distributions. However, the $\sqrt{\mathrm{x}}$ transformation was adjusted for most of these variables with the exception of the total extractable polyphenol compound contents, for which the $\sqrt{\mathrm{x}+1}$ transformation was adopted. An analysis of variance was carried out and the data were interpreted using these transformations. The data that did not show a normal distribution and did not adjust to any transformation were represented by their mean values and standard deviations. The data were also submitted to principal components analyses (PCA) in order to evaluate the response of the treatments according to the variables and to Pearson's correlation.

\section{RESULTS AND DISCUSSION}

The bunch weight was affected separately by trellis systems and production cycles, and grapevines trained to OTS yielded heavier bunches (Table 2). Comparing cycles, the second one, characterized by the highest incidence of solar radiation, produced heavier bunches. The berry weight was affected by rootstock, with 'IAC 766' providing the highest value (Table 3). 
Berry weight was also affected by the interaction between trellis systems and production cycles, with the heaviest berries produced by grapevines trained to OTS in cycle 2 (Table 4). It is worth noting that there was less variation in berry weight between productive cycles when lyre was adopted.

The canopy of plants trained to OTS captures more light due to the horizontal position of leaves, while berries are more protected from direct exposure to sunlight (Scafidi et al. 2017). Since there are several layers of leaves in an OTS, the shaded leaves inside the canopy show lower respiration rates than the leaves on the canopy surface, irrespective of temperature and

Table 2. Bunch weight, berry resistance to compression and titratable acidity of 'BRS Cora' grapes harvested from plants trained under different trellis systems or in productive cycles of the first halves of two years in the Submedium São Francisco Valley*.

\begin{tabular}{lccc}
\hline Trellis system/ Production cycle & Bunch weight $(\mathbf{g})$ & Resistance to compression (N) & $\begin{array}{c}\text { Titratable acidity } \\
\left(\mathbf{g} \text { tartaric acid·100 } \mathbf{~ L L}^{-1}\right)\end{array}$ \\
\hline Vertical shoot positioning (VSP) & $78.60 \mathrm{~b}$ & $9.39 \mathrm{~b}$ & $0.94 \mathrm{~b}$ \\
\hline Lyre & $87.07 \mathrm{~b}$ & $9.35 \mathrm{~b}$ & $1.12 \mathrm{a}$ \\
\hline Overhead trellis system (OTS) & $105.22 \mathrm{a}$ & $10.46 \mathrm{a}$ & $1.04 \mathrm{ab}$ \\
\hline Cycle 1 & $81.88 \mathrm{~B}$ & $11.03 \mathrm{~A}$ & $0.98 \mathrm{~B}$ \\
\hline Cycle 2 & $98.72 \mathrm{~A}$ & $8.43 \mathrm{~B}$ & $1.11 \mathrm{~A}$ \\
\hline CV $(\%)$ & 19.60 & 9.41 & 16.60 \\
\hline
\end{tabular}

Data of trellis systems are the average values of two rootstocks and two production cycles. Data of production cycles are the average values of three trellis systems and two rootstocks. "Means followed by the same lowercase or uppercase letter in the column do not differ from each other using the F, for production cycles, or Tukey's test, for trellis systems $(p<0.05)$. CV = coefficient of variation. Cycle $1=$ January $16^{\text {th }}$ to April $27^{\text {th }} 201$; Cycle $2=$ January $24^{\text {th }}$ to May $18^{\text {th }} 2018$.

Table 3. Berry weight of 'BRS Cora' grapes harvested from plants produced under two rootstocks in the Submedium São Francisco Valley*.

\begin{tabular}{lc}
\hline Rootstock & Berry weight (g) \\
\hline 'IAC 572' & $2.35 \mathrm{~b}$ \\
\hline 'IAC 766' & $2.44 \mathrm{a}$ \\
\hline CV (\%) & 5.64 \\
\hline
\end{tabular}

Data of rootstocks are the average values of three trellis systems and two production cycles. * Means followed by the same letter do not differ from each other using $\mathrm{F}$ test $(\mathrm{p}<0.05)$. CV = coefficient of variation.

Table 4. Berry weight, soluble solids and total soluble sugars contents of 'BRS Cora' grapes producing under three trellis systems in production cycles of the first halves of two years in the Submedium São Francisco Valley*.

\begin{tabular}{|c|c|c|c|}
\hline Trellis system & Cycle 1 & Cycle 2 & CV (\%) \\
\hline \multicolumn{4}{|c|}{ Bunch weight (g) } \\
\hline VSP & $2.00 \mathrm{bB}$ & $2.56 a \mathrm{~B}$ & \\
\hline Lyre & $2.31 \mathrm{aA}$ & $2.37 \mathrm{aC}$ & 5.64 \\
\hline OTS & $2.29 b A$ & $2.83 a \mathrm{~A}$ & \\
\hline \multicolumn{4}{|c|}{ Soluble solids content $\left({ }^{\circ} \mathrm{Brix}\right)^{\star *}$} \\
\hline VSP & $17.5 \mathrm{bB}$ & $19.2 \mathrm{aA}$ & \\
\hline Lyre & $16.8 \mathrm{bB}$ & $20.1 \mathrm{aA}$ & 2.83 \\
\hline OTS & $19.4 \mathrm{aA}$ & $20.0 \mathrm{aA}$ & \\
\hline \multicolumn{4}{|c|}{ Total soluble sugars content $\left(\mathrm{g} \cdot 100 \mathrm{~g}^{-1}\right)^{* *}$} \\
\hline VSP & $15.98 \mathrm{aAB}$ & $16.98 \mathrm{aB}$ & \\
\hline Lyre & $14.91 b B$ & 18.27aA & 3.02 \\
\hline OTS & $17.00 \mathrm{aA}$ & $17.42 \mathrm{aA}$ & \\
\hline
\end{tabular}

Data are the average values of two rootstocks. * Means followed by the same lowercase letter in the row or uppercase letter in the column comparing production cycles and trellis systems, respectively, do not differ from each other using Tukey's test $(p<0.05)$. *Variable analyzed under $\sqrt{x}$ transformation. VSP $=$ vertical shoot positioning; OTS = overhead trellis system; CV $=$ coefficient of variation. Cycle $1=$ January $16^{\text {th }}$ to April $27^{\text {th }} 2017$. Cycle $2=J$ anuary $24^{\text {th }}$ to May $18^{\text {th }} 2018$. 
leaf age. This adaptation reduces the light compensation point of photosynthesis and enables shaded leaves to maintain a positive daily net carbon balance, even though this balance is much lower than that of leaves in direct sunlight (Keller 2020). Along with this, other factors, such as water and nutrient absorption, benefit from a more effective root system distribution, derived from the use of certain rootstocks, which may regulate plant growth and crop yield (Jin et al. 2016). The 'IAC 766', which is less vigorous than 'IAC 572' (Leão and Chaves 2019), may allow greater water and nutrient absorption, thus increasing the berry weight of 'BRS Cora' grapes regardless of the trellis system adopted.

Berry resistance to compression was affected by the trellis systems, and berries from grapevines trained to lyre and VSP showed the lowest resistance to compression: 9.35 and $9.39 \mathrm{~N}$, respectively (Table 2). It was also affected by production cycle where berries in cycle 2 showed lower resistance to compression, $8.43 \mathrm{~N}$.

High temperatures and high incidence of solar radiation stimulate plant physiological events, including fruit ripening, and can therefore also cause either early or increased tissue softening because of pectin solubilization and the degradation of other cell wall compounds. These changes lead to reduced berry resistance to compression (Ribeiro et al. 2012) and can therefore explain the lower values observed in berries of grapevines trained to lyre and VSP in cycle 2, characterized by higher temperature and solar radiation. Moreover, variations in berry resistance to compression can also be affected by water pressure inside the fruits (Jin et al. 2016).

Regarding the skin color attributes, the values for $a^{*}$ and $b^{*}$ did not have normal distribution (Table 5). In cycle 1 , the values for $a^{\star}$ ranged from 0.18 , in berries from grapevines grafted to 'IAC 766 ' and trained onto lyre, to 2.25 , for berries trained to VSP with rootstock 'IAC 572'. In cycle 2, the variations in $a^{\star}$ for berries from grapevines trained with a VSP with 'IAC 572 ' ranged from -0.48 to 1.88 . As for the color attribute $b^{*}$, in cycle 1 , the values varied from -3.64 for berries trained to lyre with rootstock 'IAC 766 ' to -1.59 for grapevines trained to VSP and grafted onto 'IAC 572'. In cycle 2, they varied from -1.92 for berries from grapevines trained to VSP and grafted onto 'IAC 766', to -0.25 when trained to OTS associated with 'IAC 766'.

The coloration of red grapes is determined by anthocyanic compounds, and the synthesis and accumulation of these compounds may be affected by combinations between trellis systems and rootstocks (Jin et al. 2016). Observing the values

Table 5. Mean values and standard deviations of the variables skin colour attributes $a^{\star}$ and $b^{\star}$, and the antioxidant activity as determined by evaluating the free radical DPPH• in 'BRS Cora' grapes, affected by the trellis system, rootstock, and production cycle of the first half of the year, in the Submedium São Francisco Valley ${ }^{1}$.

\begin{tabular}{|c|c|c|c|c|}
\hline \multirow{2}{*}{ Trellis system } & \multicolumn{2}{|c|}{ Cycle 1} & \multicolumn{2}{|c|}{ Cycle 2} \\
\hline & 'IAC 572’ & 'IAC 766' & 'IAC 572' & 'IAC 766’ \\
\hline & \multicolumn{4}{|c|}{$a^{*}$} \\
\hline VSP & $1.48 \pm 0.77$ & $1.52 \pm 0.71$ & $0.70 \pm 1.18$ & $0.21 \pm 0.16$ \\
\hline Lyre & $0.78 \pm 0.15$ & $0.63 \pm 0.45$ & $0.59 \pm 0.53$ & $0.39 \pm 0.29$ \\
\hline OTS & $0.53 \pm 0.18$ & $0.71 \pm 0.20$ & $0.09 \pm 0.05$ & $0.21 \pm 0.08$ \\
\hline \multirow[t]{2}{*}{ CV (\%) } & \multicolumn{4}{|c|}{65.02} \\
\hline & \multicolumn{4}{|c|}{$b^{\star}$} \\
\hline VSP & $-2.61 \pm 1.02$ & $-2.43 \pm 0.73$ & $-1.01 \pm 0.48$ & $-1.27 \pm 0.65$ \\
\hline Lyre & $-2.82 \pm 0.41$ & $-3.00 \pm 0.64$ & $-0.95 \pm 0.55$ & $-0.87 \pm 0.24$ \\
\hline OTS & $-2.58 \pm 0.35$ & $-2.16 \pm 0.22$ & $-0.79 \pm 0.40$ & $-0.53 \pm 0.28$ \\
\hline \multirow[t]{2}{*}{ CV (\%) } & \multicolumn{4}{|c|}{24.93} \\
\hline & \multicolumn{4}{|c|}{ Antioxidant activity by the DPPH method $\left(\mathrm{g} \cdot \mathrm{g}^{-1} \mathrm{DPPH}\right)$} \\
\hline VSP & $5643 \pm 436$ & $5776 \pm 600$ & $4681 \pm 249$ & $3729 \pm 262$ \\
\hline Lyre & $3612 \pm 121$ & $3640 \pm 79$ & $4350 \pm 207$ & $4075 \pm 121$ \\
\hline OTS & $3417 \pm 229$ & $3454 \pm 197$ & $3357 \pm 99$ & $3095 \pm 69$ \\
\hline CV (\%) & & & & \\
\hline
\end{tabular}

${ }^{1}$ Data did not have a normal distribution with either their original values or after transformation. VSP = vertical shoot positioning; OTS = overhead trellis system; $\mathrm{CV}=$ coefficient of variation. Cycle $1=$ January $16^{\text {th }}$ to April $27^{\text {th }} 2017$. Cycle $2=$ January $24^{\text {th }}$ to May $18^{\text {th }} 2018$. 
of each trellis system-rootstock-cycle combination, grapes from grapevines trained to lyre and OTS grafted onto both rootstocks showed a stronger violet blue color in cycle 1, indicated by more negative values. Vertical shoot positioning caused a greater variation in coloration in cycle 1, including values that were observed in cycle 2. As the synthesis of pigments is primarily represented by the synthesis of anthocyanins, it is affected by both solar radiation and the temperature. This influence is explained by the sensibility of enzymes such as phenylalanine ammonium lyase (PAL), a precursor of the phenolic compound pathway, to these factors (Wang et al. 2015). The more negative $b^{*}$ values in berries from grapevines trained to lyre and OTS in cycle 1 might be explained by the arrangements of the shoots and leaves that protect the grape berries from overheating in a high-irradiance ambient (Keller 2020). However, the inconsistent response for the production cycles signals a certain limit to the protection.

Titratable acidity was affected separately by trellis systems, with VSP providing the lowest acidity, followed by lyre (Table 2). This variable was also affected by production cycles, with the lowest values recorded in cycle 1.

The soluble solids and total soluble sugars contents were influenced by the interaction between the trellis systems and production cycles (Table 4). In cycle 1, the berries from the OTS treatment showed higher soluble solids and total soluble sugars contents. In cycle 2, no significant difference was observed between the trellis systems for the soluble solids content while berries from grapevines trained to lyre and OTS had higher total soluble sugars contents. Importantly, OTS provided a smaller variation between the cycles for both variables.

The sugars and organic acid contents are determining for the sensory quality of grapes (Jin et al. 2016) and both are influenced by environmental and cropping factors. Higher temperatures and greater solar radiation change the metabolite concentrations, leading to greater accumulation of sugars and degradation of organic acids due to increased respiration (Martínez-Lüscher et al. 2016). To the contrary, relatively lower temperatures during berry ripening, as occur in harvest seasons during the first half of the year in Brazilian semiarid region, reduce the degradation rate of organic acids (Ferreira el al. 2019).

Additionally, the water supply also changes sugar concentration. If the water supply is not restricted, grape sugar contents may be lower due to competition for carbon between berry ripening and shoot growth and to dilution of chemical compounds in a greater berry volume (van Leeuwen et al. 2009). In the present study, with a proper availability of water to the plants by controlled irrigation, greater solar radiation may have provided greater availability of carbohydrates to the berries, resulting in higher soluble solids and sugars contents.

Regardless of cropping factors, in a subtropical-dry winter climate, a less stratified canopy due to the removal of tertiary shoots caused greater soluble solids contents and titratable acidity in berries from grapevines trained to VSP, as compared to the OTS (Sanchez-Rodriguez and Spósito 2020). The cultivation of grapevines for processing does not require a specific canopy management. This justifies the observation that 'BRS Cora' grapes grown under a system that intercept more solar radiation, such as OTS, have higher soluble sugars contents and titratable acidity.

The yellow flavonoids and total anthocyanins in the skin, as well as the total extractable polyphenol compound contents and the antioxidant activity determined using the $\mathrm{ABTS}^{*}$ method were affected by the interaction between the trellis systems, rootstocks and cycles (Table 6). The use of the lyre associated with 'IAC 572' provided greater stability to the contents of these compounds in both cycles, suggesting reduced influence, at least to a certain extent, of the variations in the climatic factors (Table 1). VSP and OTS provided greater accumulation of yellow flavonoids with both rootstocks in cycle 2, characterized by greater solar radiation.

Even though VSP is characterized by a dense vegetative canopy architecture, the relatively lower vigor of the rootstock 'IAC 766', as mentioned before, may have allowed sufficient capture of solar radiation to ensure good accumulation of these compounds. Pastore et al. (2017) suggested a dominant influence of sunlight in the synthesis of different flavonoids, particularly the flavonols, but others factors, including the genotype and the synergistic or antagonistic effect of both the temperature and light intensity experienced by the berries, must be considered.

A physiological disorder named berry shrivel occurred at the end of maturation in cycle 2. According to Bondada and Keller (2012), the cause of berry shrivel are still unknown, but although the berries start looking similar to golf balls due to skin grooves, the peduncle, rachis and pedicels remain healthy. The authors also emphasized that the disorder has no significant effects on the main grape quality characteristics, although yield is compromised. 
Table 6. Yellow flavonoids, total anthocyanins, total extractable polyphenol compound contents and antioxidant activity as determined by the free radical ABTS ${ }^{\bullet+}$ of 'BRS Cora' grapes influenced by three trellis system, rootstock and production cycle of the first half of the year in the Submedium São Francisco Valley*.

\begin{tabular}{|c|c|c|c|c|}
\hline \multirow{2}{*}{ Trellis system } & \multicolumn{2}{|c|}{ Cycle 1} & \multicolumn{2}{|c|}{ Cycle 2} \\
\hline & 'IAC 572’ & 'IAC 766’ & 'IAC 572’ & ‘IAC 766’ \\
\hline \multicolumn{5}{|c|}{ Yellow flavonoids content $\left(\mathrm{mg} \cdot 100 \mathrm{~g}^{-1}\right)^{\star \star}$} \\
\hline VSP & $59.25 b A b$ & $70.79 b A a$ & $76.04 a \mathrm{Ab}$ & $83.08 a \mathrm{Aa}$ \\
\hline Lyre & $49.76 a \mathrm{Ba}$ & $51.97 a \mathrm{Ba}$ & $45.17 a \mathrm{Ba}$ & $40.41 b \mathrm{Cb}$ \\
\hline OTS & $51.06 b \mathrm{Ba}$ & $44.74 b \mathrm{Cb}$ & $74.45 a \mathrm{Aa}$ & $74.46 a \mathrm{Ba}$ \\
\hline \multicolumn{5}{|l|}{$\mathrm{CV}(\%)$} \\
\hline \multicolumn{5}{|c|}{ Total anthocyanins content $\left(\mathrm{mg} \cdot 100 \mathrm{~g} \mathrm{~g}^{-1}\right)^{\star \star}$} \\
\hline VSP & $177.59 b B b$ & $223.49 \mathrm{bCa}$ & $1517.03 a \mathrm{Ab}$ & $1874.08 a \mathrm{Aa}$ \\
\hline Lyre & $181.58 b \mathrm{Bb}$ & $264.74 b \mathrm{Ba}$ & $1042.31 a \mathrm{Bb}$ & $1603.79 a \mathrm{Ba}$ \\
\hline OTS & $276.93 b A a$ & $288.99 b A a$ & $1506.55 a \mathrm{Ab}$ & $1642.13 a \mathrm{Ba}$ \\
\hline CV (\%) & & & & \\
\hline \multicolumn{5}{|c|}{ tal extractable polyphenol compound content (mg gallic acid·100 $\left.\mathrm{g}^{-1}\right)^{\star \star \star *}$} \\
\hline VSP & $147.83 b B b$ & $227.65 b \mathrm{Ca}$ & 287.81aBa & $301.92 a \mathrm{Ba}$ \\
\hline Lyre & $288.09 a \mathrm{Aa}$ & $301.65 a \mathrm{Ba}$ & $273.31 a \mathrm{Ba}$ & $297.30 a \mathrm{Ba}$ \\
\hline OTS & $301.63 a \mathrm{Ab}$ & $336.16 a A a$ & $327.24 a A a$ & $348.02 a \mathrm{Aa}$ \\
\hline CV (\%) & & & & \\
\hline \multicolumn{5}{|c|}{ Antioxidant activity by the ABTS ${ }^{+}$method $\left(\mu \mathrm{mol} \cdot \mathrm{L}^{-1} \text { Trolox } \cdot \mathrm{g}^{-1}\right)^{\star \star}$} \\
\hline VSP & $12.02 \mathrm{aBa}$ & $10.91 b \mathrm{Ca}$ & $10.99 a \mathrm{Bb}$ & $18.15 a \mathrm{Aa}$ \\
\hline Lyre & $16.34 a \mathrm{Aa}$ & $14.95 a \mathrm{Ba}$ & $10.72 b \mathrm{Bb}$ & $12.57 \mathrm{bBa}$ \\
\hline OTS & $16.05 a \mathrm{Aa}$ & $17.27 a \mathrm{Aa}$ & $16.53 a \mathrm{Aa}$ & $16.39 a \mathrm{Aa}$ \\
\hline CV (\%) & & & & \\
\hline
\end{tabular}

"Means followed by the same lowercase letter in italics in the same row, comparing production cycles within each trellis system interacting with each rootstock, and uppercase letters in the same column, comparing trellis systems within each production cycle interacting with each rootstock, do not statistically differ from each other using Tukey's test $(p<0.05$ ). Means followed by the same lowercase letter in bold in the same row, comparing rootstocks within each production

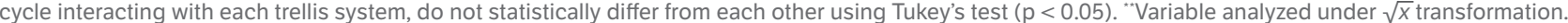
${ }^{* *}$ Variable analyzed under $\sqrt{\mathrm{x}+1}$ transformation. VSP $=$ vertical shoot positioning; OTS = overhead trellis system; CV = coefficient of variation. Cycle $1=$ January $16^{\text {th }}$ to April $27^{\text {th }} 2017$. Cycle $2=$ January $24^{\text {th }}$ to May $18^{\text {th }} 2018$.

The fact of not affecting most of the quality attributes is corroborated by the observation that only total anthocyanin contents of the skin appear to be affected by the disorder, although this in a marked way. This phenomenon possibly justifies the great variation in anthocyanin contents in the skin between cycles, where the higher contents in cycle 2 may be explained by the progressive loss of cell membrane integrity due to shrivel, resulting in leakage of the anthocyanins (Rubinstein 2000).

Berry shrivel did not appear in cycle 1 and OTS provided the highest total anthocyanin contents in berry skins, with values of $276.93 \mathrm{mg} 100 \mathrm{~g}^{-1}$, in the treatment with rootstock 'IAC 572', and $288.99 \mathrm{mg} 100 \mathrm{~g}^{-1}$ when the rootstock used was 'IAC 766' (Table 6).

Similar to the yellow flavonoid contents, the variation in total extractable polyphenol compounds in the berries from grapevines trained to lyre was the lowest between productive cycles (Table 6). Grapevines trained to VSP and OTS, both associated with rootstock 'IAC 766', showed a higher accumulation of polyphenols in berries in cycle 1, with 227.65 and $336.16 \mathrm{mg}$ of gallic acid $\cdot 100 \mathrm{~g}^{-1}$, respectively, while there were no differences between the rootstocks in cycle 2 .

Apart from the behavior of trellis systems associated with the rootstocks concerning interception of solar radiation, vigorous rootstocks can influence the canopy development inducing a greater leaf area and yield efficiency. An effect of the soluble carbohydrates on the fruits and leaves can be also observed. The crop load is another component that should be considered, since it affects the leaf photosynthetic rate, leaf carbohydrates and fruit size (Mesa et al. 2016). Conversely, less vigorous rootstocks can result in greater synthesis and accumulation of phenolic compounds in the berries. 
The systems showing greater incident light capture (lyre and OTS) showed greater stability for some quality characteristics and for the phenolic compound composition in productive cycles related to the same season of the year. This characteristic helps in the prior choice of which trellis system to adopt in the vineyard, since it is useful for estimating the quality of the grapes and their products or by-products, throughout the harvests.

Lower competition between vegetative and productive organs for photoassimilates or higher exposure of bunches to sunlight provided by a less dense canopy, as observed in vines grafted onto less vigorous rootstocks, e.g., 'IAC 766' (as compared to 'IAC 572'), may result in greater accumulation of phenolic compounds in the grapes (Dias et al. 2017). It is worth noting that rootstock vigor may induce leaf formation and increase canopy density, which might affect grape quality. This inferred that 'IAC 766' associated with VSP and OTS allowed sufficient opening of the canopy to ensure enough light incidence to stimulate the synthesis of phenols. Ferreira et al. (2019) reported that productive cycles with high temperatures associated with high solar radiation interception during grape ripening showed greater biosynthesis of phenolic compounds, since it is related to exposure of the fruits to stress.

Regarding antioxidant activity using $\mathrm{ABTS}^{*+}$, in cycle 1 there was no difference between the rootstocks with respect to the different trellis systems (Table 6). In cycle 2, berries trained to OTS showed no difference between the rootstocks. It is worth noting that the OTS provided the lowest variation in antioxidant activity between the berries in both productive cycles.

The antioxidant activity values determined by the $\mathrm{DPPH}^{*}$ method did not show normal distribution (Table 6 ). In cycle 1 , the values ranged from $3188 \mathrm{~g} \cdot \mathrm{g}^{-1} \mathrm{DPPH}$ in berries trained to OTS with rootstock 'IAC 572', to $6376 \mathrm{~g} \cdot \mathrm{g}^{-1} \mathrm{DPPH}$ in those

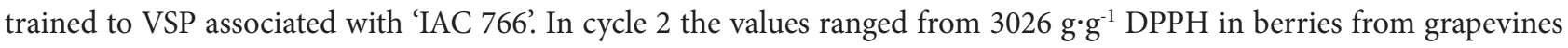
trained to OTS with rootstock 'IAC 766', to $4930 \mathrm{~g} \cdot \mathrm{g}^{-1} \mathrm{DPPH}$ for the VSP associated with 'IAC 572'. The highest antioxidant activity, characterized by the lowest values, was observed for berries from grapevines trained to OTS in both cycles. The OTS trellis system also resulted in a smaller variation in antioxidant activity between the cycles.

Thus, berries with higher antioxidant activity and greater stability were provided by trellis systems with a greater incidence of solar radiation in the canopy in both cycles of the same season of the year. This response was expected since grape antioxidant activity is related to the phenolic compounds. The antioxidant potential of the phenolics, as well as the health benefit properties attributed to them, particularly in the control or prevention of factors related to the metabolic syndrome and age-related chronic diseases, explain the incentives for consuming grapes and their derivatives (Antoniolli et al. 2015).

Based on the PCA, components 1 and 2 explained $77.82 \%$ of data variation (Fig. 1). The total extractable polyphenol compound content was the variable that best contributed to distinguishing the OTS associated with rootstock 'IAC 572' in cycle 2 (OTSR1C2) from the OTS associated with 'IAC 766' in cycle 2 (OTSR2C2). In cycle 2, the total anthocyanin and total soluble sugars contents better characterized the difference in grape quality between the use of the lyre associated with 'IAC 572' (LR1C2), the lyre associated with 'IAC 766' (LR2C2), VSP associated with 'IAC 572' (VSPR1C2), and VSP associated with 'IAC 766' (VSPR2C2). The antioxidant activity determined using the DPPH' method, distinguished the treatments VSP associated with 'IAC 572' in cycle 1 (VSPR1C1) from VSP with 'IAC 766' in cycle 1 (VSPR2C1). On the other hand, for cycle 1 , the color attribute $b^{*}$ distinguished the lyre associated with 'IAC 766' (LR2C1) from the lyre associated with 'IAC 572' (LR1C1), OTS associated with 'IAC 572' (OTSR1C1), and OTS with 'IAC 766' (OTSR2C1). It is worth noting that OTSR1C2, OTSR2C2, LR1C2, LR2C2, VSPR1C2, and VSPR2C2 can be found in one quadrant of the graph, while LR1C1, LR2C1, VSPR1C1, VSPR2C1, OTSR1C1, and OTSR2C1 can be found in another, emphasizing the differentiation according to productive cycles, even if harvests occur in the same halves of both years.

The major variables affected by the trellis systems and rootstocks were the total extractable polyphenol compound contents, the total anthocyanin contents, the antioxidant activity by the $\mathrm{DPPH}^{*}$ method and the color attribute $b^{*}$, affected by pigments such as the anthocyanins. This response was due to the effect of canopy management on the interception of solar radiation and microclimate around the bunch (Pastore et al. 2017), which, in turn, affected pigment synthesis or degradation (Leão and Lima 2018) and that of other phenolic compounds (Ferreira et al. 2019). This influence was attributed to the sensitivity of PAL (which catalyzes the reaction in the first phenolic pathway step) to climatic factors such as solar radiation (Wang et al. 2015).

The correlations were positive with coefficients above 0.70 between bunch and berry weights, soluble solids content and total soluble sugars contents and total anthocyanins contents and skin color attribute $b^{*}$ (Table 7). The correlations were 


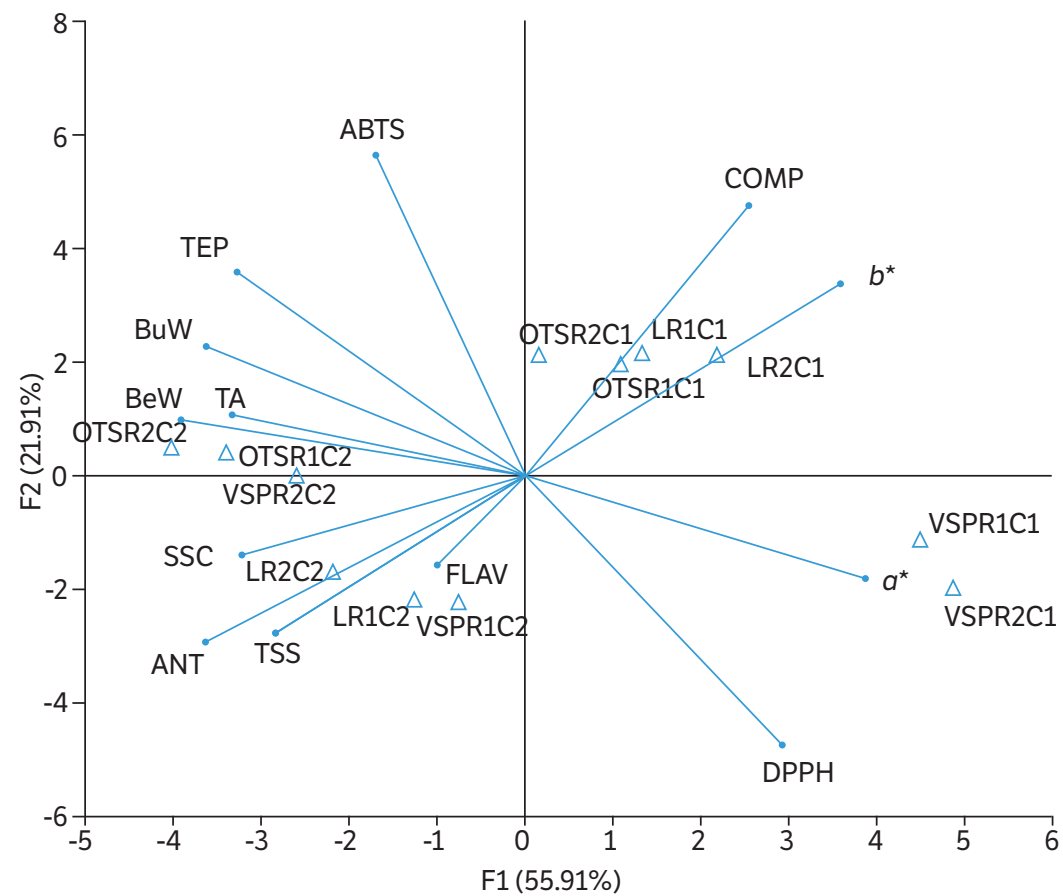

Variables: Bunch weight (BuW), berry weight (BeW), soluble solids content (SSC), total soluble sugars content (TSS), titratable acidity (TA), berry resistance to compression (COMP), yellow flavonoids in the grape skin (FLAV), total anthocyanins in the grape skin (ANT), total extractable polyphenol compound content (TEP), antioxidant activity by capturing methods of free radical ABTS ${ }^{\bullet+}$ and DPPH ${ }^{\bullet} a^{\star}$ e $b^{\star}$ skin colour attributes. Treatments: overhead trellis system (OTS); vertical shoot position (VSP); Iyre (L); rootstock 'IAC 572' (R1); rootstock 'IAC 766' (R2), Cycle 1 - January $16^{\text {th }}$ to April $27^{\text {th }} 2017$ (C1); Cycle $2-$ January $24^{\text {th }}$ to May $18^{\text {th }} 2018$ (C2)

Figure 1. Principal components analysis of the variables determining the quality and antioxidant potential of 'BRS Cora' grapes under influence of trellis system, rootstock, and production cycle of the first half of the year in the Submedium São Francisco Valley.

Table 7. Pearson's correlation coefficients for bunch weight (BuW), berry weight (BeW), soluble solids content (SSC), total soluble sugars content (TSS), titratable acidity (TA), berry resistance to compression (COMP), yellow flavonoids in the grape skin (FLAV), total anthocyanins in the grape skin (ANT), total extractable polyphenol compound content (TEP), antioxidant activity by the free radical capturing methods $\mathrm{ABTS}^{+}$and DPPH${ }^{*}, a^{\star}$ and $b^{\star}$ skin color attributes of 'BRS Cora' grapes under the influence of trellis system, rootstock, and production cycle of the first half of the year in the Submedium São Francisco Valley ${ }^{1}$

\begin{tabular}{|c|c|c|c|c|c|c|c|c|c|c|c|c|}
\hline Variable & BeW & SSC & TSS & TA & COMP & FLAV & ANT & TEP & ABTS & DPPH & $a^{*}$ & $b^{\star}$ \\
\hline BuW & 0.730 & 0.327 & 0.249 & 0.276 & -0.198 & 0.139 & 0.432 & 0.557 & 0.419 & -0.591 & -0.431 & 0.401 \\
\hline $\mathrm{BeW}$ & & 0.382 & 0.288 & 0.538 & -0.259 & 0.390 & 0.656 & 0.606 & 0.465 & -0.622 & -0.674 & 0.511 \\
\hline SSC & & & 0.929 & 0.288 & -0.316 & 0.023 & 0.563 & 0.429 & 0.159 & -0.289 & -0.411 & 0.473 \\
\hline TSS & & & & 0.236 & -0.434 & -0.045 & 0.553 & 0.275 & -0.032 & -0.122 & -0.288 & 0.463 \\
\hline TA & & & & & -0.123 & -0.057 & 0.377 & 0.443 & 0.234 & -0.473 & -0.644 & 0.117 \\
\hline COMP & & & & & & -0.175 & -0.701 & -0.031 & 0.348 & -0.112 & 0.074 & -0.728 \\
\hline FLAV & & & & & & & 0.386 & -0.065 & 0.133 & 0.082 & -0.142 & 0.278 \\
\hline ANT & & & & & & & & 0.407 & 0.030 & -0.265 & -0.473 & 0.834 \\
\hline TEP & & & & & & & & & 0.670 & -0.865 & -0.583 & 0.297 \\
\hline ABTS & & & & & & & & & & -0.774 & -0.438 & -0.105 \\
\hline DPPH & & & & & & & & & & & 0.631 & -0.151 \\
\hline$a^{*}$ & & & & & & & & & & & & -0.192 \\
\hline
\end{tabular}

${ }^{1}$ The values in bold are statistically significant by $t$ test $(p<0.05)$. 
negative with coefficients above 0.70 between berry resistance do compression and the total anthocyanin content, berry resistance do compression and $b^{*}$, total extractable polyphenol compound contents and antioxidant activity as determined by the $\mathrm{DPPH}^{\cdot}$ method, and between the both methods adopted to determine antioxidant activity. Important correlations were also observed between the antioxidant activity by the $\mathrm{ABTS}^{*+}$ method and the total extractable polyphenol compound contents, and between the antioxidant activity as determined by the DPPH• method and the color attribute $a^{*}$.

High correlation coefficients were mostly observed between variables that have the same nature or shared chemical pathways, such as soluble solids and sugars. In this case, total soluble sugars are the main constituents of the soluble solids. The high correlation between the total extractable polyphenol compound contents and antioxidant activity using the DPPH method, as well as between the total anthocyanins content and the color attribute $b^{*}$, corroborates the assumption that the grape antioxidant activity is directly related to secondary metabolism compounds (Di Lorenzo et al. 2017), e.g., anthocyanins (Leão and Lima 2018). Furthermore, the correlation between the methods used to determine antioxidant activity indicated that adopting either method led to consistent conclusions between the both years (Di Lorenzo et al. 2017).

\section{CONCLUSION}

The use of the trellis system lyre associated with rootstock 'IAC 572' provided a more uniform quality for the industry since yellow flavonoids, anthocyanins, total extractable polyphenols contents and antioxidant activity of 'BRS Cora' grapes were practically stable between the production cycles of the first halves of both years (2017 and 2018). These characteristics enhance the functional appeal of the elaborated juices. In these conditions, grapes from plants trained to overhead trellis system had the high levels of yellow flavonoids and antioxidant activity as a quality differential, regardless of the rootstock. The distinction of grapes quality, particularly by the higher polyphenols contents, was also possible through the use of overhead trellis system with rootstock 'IAC 766.

\section{AUTHORS' CONTRIBUTION}

Conceptualization: Lima M. A. C.; Methodology: Lima M. A. C. and Costa, R. R.; Investigation: Lima M. A. C., Costa, R. R. and Ferreira, T. O.; Writing - Original Draft: Costa, R. R.; Writing - Review and Editing: Lima M. A. C. and Costa, R. R.; Funding Acquisition: Lima M. A. C.; Resources: Lima M. A. C.; Supervision: Lima M. A. C.

\section{DATA AVAILABILITY STATEMENT}

All dataset were generated and analyzed in the current study.

\section{FUNDING}

Empresa Brasileira de Pesquisa Agropecuária

[https://doi.org/10.13039/]

Grant No. 02.13.06.005.00.00

Coordenação de Aperfeiçoamento de Pessoal de Nível Superior

[https://doi.org/10.13039/501100002322]

Finance Code 001 


\section{ACKNOWLEDGMENTS}

Not applicable.

\section{REFERENCES}

[Embrapa] Empresa Brasileira de Pesquisa Agropecuária. (2017). Médias anuais da estação agrometeorológica de Bebedouro, Petrolina-PE. Embrapa Semiárido. [Accessed Jan. 20, 2019]. Available at: https://www.embrapa.br/semiarido/laboratorios/agrometeorologia

[Embrapa] Empresa Brasileira de Pesquisa Agropecuária. (2018). Médias anuais da estação agrometeorológica de Bebedouro, Petrolina-PE. Embrapa Semiárido. [Accessed Jan. 20, 2019]. Available at: https://www.embrapa.br/semiarido/laboratorios/agrometeorologia

Alvares, C. A., Stape, J. L., Sentelhas, P. C., Gonçalves, J. L. M. and Sparovek, G. (2013). Köppen’s climate classification map for Brazil. Meteorologische Zeitschrift, 22, 711-728. https://doi.org/10.1127/0941-2948/2013/0507

Antoniolli, A., Fontana, A. R., Piccoli, P. and Bottini, R. (2015). Characterization of polyphenols and evaluation of antioxidant capacity in grape pomace of the cv. Malbec. Food Chemistry, 178, 172-178. https://doi.org/10.1016/j.foodchem.2015.01.082

Bondada, B. R. and Keller, M. (2012). Not all shrivels are created equal-morpho-anatomical and compositional characteristics differ among different shrivel types that develop during ripening of grape (Vitis vinifera L.) berries. American Journal of Plant Sciences, 3, 879898. https://doi.org/10.4236/ajps.2012.37105

Dias, F. A. N., Mota, R. V., Souza, C. R., Pimentel, R. M. A., Souza, L. C., Souza, A. L. and Regina, M. A. (2017). Rootstock on vine performance and wine quality of 'Syrah' under double pruning management. Scientia Agricola, 74, 134-141. https://doi.org/10.1590/1678-992x-2015-0384

Di Lorenzo, C., Badea, M., Colombo, F., Orgiu, F., Frigerio, G., Pastor, R. F. and Restani, P. (2017). Antioxidant activity of wine assessed by different in vitro methods. BIO Web of Conferences, 9, 04008. https://doi.org/10.1051/bioconf/20170904008

Ferreira, T. O., Costa, R. R., Felix, D. T., Andrade Neto, E. R., Cruz, M. M. and Lima, M. A. C. (2019). Quality and antioxidant potential of 'BRS Magna' grapes harvested in the first half of the year under different training systems and rootstocks in a tropical region. Ciência e Agrotecnologia, 43, e029518. https://doi.org/10.1590/1413-7054201943029518

Francis, F. J. (1982). Chapter 7 - Analysis of Anthocyanins. In P. Markakis (Ed.), Anthocyanins as food colors (p. 181-207). Cambridge: Academic Press. https://doi.org/10.1016/B978-0-12-472550-8.50011-1

Horwitz, W. (2010). Official methods of analysis of the Association of the Agricultural Chemists. Washington: AOAC.

Jin, Z.-X., Sun, T.-Y., Sun, H., Yue, Q.-Y. and Yao, Y.-X. (2016). Modifications of ‘Summer Black’ grape berry quality as affected by the different rootstocks. Scientia Horticulturae, 210, 130-137. https://doi.org/10.1016/j.scienta.2016.07.023

Keller, M. (2020). The science of grapevines. Cambridge: Academic Press. https://doi.org/10.1016/C2017-0-04744-4

Larrauri, J. A., Rupérez, P. and Saura-Calixto, F. (1997). Effect of drying temperature on the stability of polyphenols and antioxidant activity of red grape pomace peels. Journal of Agricultural and Food Chemistry, 45, 1390-1393. https://doi.org/10.1021/jf960282f

Leão, P. D. S., Soares, J. M., Rodrigues, B. L., Soares, J. and Leão, P. (2009). A vitivinicultura no Semiárido brasileiro. Brasília: Embrapa Informação Tecnológica Embrapa Semiárido.

Leão, P. C. S. and Chaves, A. R. M. (2019). Training systems and rootstocks on yield and agronomic performance of ‘Syrah' grapevine in the Brazilian semiarid. Ciência e Agrotecnologia, 43, e005719. https://doi.org/10.1590/1413-7054201943005719

Leão, P. C. S. and Lima, M. A. C. (2018). Canopy Management of table grapes cultivar in tropical conditions. Journal of Agricultural Science and Technology B, 8, 228-233. https://doi.org/10.17265/2161-6264/2018.04.004 
Leão, P. C. S., Rego, J. I. S., Nascimento, J. H. B. and Souza, E. M. C. (2018). Yield and physicochemical characteristics of 'BRS Magna' and 'Isabel Precoce' grapes influenced by pruning in the São Francisco river valley. Ciência Rural, 48, e20170463. https://doi. org/10.1590/0103-8478cr20170463

Martínez-Lüscher, J., Sánchez-Días, M., Delrot, S., Aguirreolea, J., Pascual, I. and Gomès, E. (2016). Ultraviolet-B alleviates the uncoupling effect of elevated $\mathrm{CO}_{2}$ and increased temperature on grape berry (Vitis vinifera cv. Tempranillo) anthocyanin and sugar accumulation. Australian Journal of Grape and Wine Research, 22, 87-95. https://doi.org/10.1111/ajgw.12213

Mesa, K., Serra, S., Masia, A., Gagliardi, F., Bucci, D. and Musacchi, S. (2016). Seasonal trends of starch and soluble carbohydrates in fruits and leaves of 'Abbé Fétel' pear trees and their relationship to fruit quality parameters. Scientia Horticulturae, 211, 60-69. https:// doi.org/10.1016/j.scienta.2016.08.008

Miele, A. and Rizzon, L. A. (2017). Rootstock-Scion Interaction: 1. Effect on the yield components of Cabernet Sauvignon grapevine. Revista Brasileira de Fruticultura, 39, e-434. https://doi.org/10.1590/0100-29452017820

Miller, N. J., Rice-Evans, C., Davies, M. J., Gopinathan, V. and Milner, A. (1993). A novel method for measuring antioxidant capacity and its application to monitoring the antioxidant status in premature neonates. Clinical Science, 84, 407-412. https://doi.org/10.1042/cs0840407

Pastore, C., Allegro, G., Valentini, G., Muzzi, E. and Filippetti, I. (2017). Anthocyanin and flavonol composition response to veraison leaf removal on Cabernet Sauvignon, Nero d’Avola, Raboso Piave and Sangiovese Vitis vinifera L. cultivars. Scientia Horticulturae, 218, 147155. https://doi.org/10.1016/j.scienta.2017.01.048

Ribeiro, T. P., Lima, M. A. C. and Alves, R. E. (2012). Maturação e qualidade de uvas para suco em condições tropicais, nos primeiros ciclos de produção. Pesquisa Agropecuária Brasileira, 47, 1057-1065. https://doi.org/10.1590/S0100-204X2012000800005

Rubinstein, B. (2000) Regulation of cell death in flower petals. Plant Molecular Biology, 44, 303-318. https://doi.org/10.1023/A:1026540524990

Sánchez-Moreno, C., Larrauri, J. A. and Saura-Calixto, F. (1998). A procedure to measure the antiradical efficiency of polyphenols. Journal of the Science of Food and Agriculture, 76, 270-276. https://doi.org/10.1002/(SICI)1097-0010(199802)76:2\%3C270::AID-JSFA945\%3E3.0.CO;2-9

Sanchez-Rodriguez, L. A. and Spósito, M. B. (2020). Influence of the trellis/training system on the physiology and production of Vitis labrusca cv. Niagara Rosada in Brazil. Scientia Horticulturae, 261, 109043. https://doi.org/10.1016/j.scienta.2019.109043

Scafidi, P., Barbagallo, M. G., Pisciotta, A., Mazza, M. and Downey, M. O. (2017). Defoliation of two-wire vertical trellis: effect on grape quality. New Zealand Journal of Crop and Horticultural Science, 46, 18-38. https://doi.org/10.1080/01140671.2017.1337642

van Leeuwen, C., Trégoat, O., Choné, X., Bois, B., Pernet, D. and Gaudillère, J.-P. (2009). Vine water status is a key factor in grape ripening and vintage quality for red Bordeaux wine. How can it be assessed for vineyard management purposes? Journal International des Sciences de la Vigne et du Vin, 43, 121-134. https://doi.org/10.20870/oeno-one.2009.43.3.798

Wang, J.-F, Ma, L., Xi, H.-F, Wang, L.-J. and Li, S.-H (2015). Resveratrol synthesis under natural conditions and after UV-C irradiation in berry skin is associated with berry development stages in 'Beihong' (V. vinifera $\times$ V. amurensis). Food Chemistry, 168, 430-438. https:// doi.org/10.1016/j.foodchem.2014.07.025

Yemm, E. W. and Willis, A. J. (1954). The estimation of carbohydrate in plant extracts by anthrone. Biochemical Journal, 57, 508-514. https://doi.org/10.1042/bj0570508 